\title{
Article \\ Development of an Improved Micropropagation Protocol for Red-Fleshed Pitaya 'Da Hong' with and without Activated Charcoal and Plant Growth Regulator Combinations
}

\author{
Yu-Chi Lee ${ }^{1,2}$ and Jer-Chia Chang ${ }^{2, *}$ \\ 1 Agricultural Management Research Section, Taichung District Agricultural Research and Extension Station, \\ No. 370 Song Hwai Road, Tatsuen Township, Changhua 515, Taiwan; klyc1512@tdais.gov.tw \\ 2 Department of Horticulture, National Chung-Hsing University, No. 145, Xingda Road, South Dist., \\ Taichung 40227, Taiwan \\ * Correspondence: jerchiachang@dragon.nchu.edu.tw; Tel.: +886-4-22840340 (ext. 403); Fax: +886-4-22856974
}

Citation: Lee, Y.-C.; Chang, J.-C. Development of an Improved Micropropagation Protocol for Red-Fleshed Pitaya 'Da Hong' with and without Activated Charcoal and Plant Growth Regulator Combinations. Horticulturae 2022, 8, 104. https://doi.org/10.3390/ horticulturae8020104

Academic Editors: Jean Carlos Bettoni, Min-Rui Wang and Qiao-Chun Wang

Received: 4 January 2022 Accepted: 21 January 2022 Published: 25 January 2022

Publisher's Note: MDPI stays neutral with regard to jurisdictional claims in published maps and institutional affiliations.

Copyright: (c) 2022 by the authors. Licensee MDPI, Basel, Switzerland. This article is an open access article distributed under the terms and conditions of the Creative Commons Attribution (CC BY) license (https:// creativecommons.org/licenses/by/ $4.0 /)$.

\begin{abstract}
Micropropagation protocols for red-fleshed Hylocereus species (Cactaceae) have been developed; however, these methods prolong the sprout duration from areoles and produce irregular micro-propagules in 'Da Hong' pitaya. Thus, the present study aimed to establish an improved micropropagation protocol for this cultivar. Shoot regeneration and root induction of self-pollinating seedling segments were evaluated in response to combinations of activated charcoal (AC; $200 \mathrm{mg} / \mathrm{L}$ ), $\alpha$-naphthaleneacetic acid (NAA; 0.05, 0.10, and $0.20 \mathrm{mg} / \mathrm{L}$ ), and 6-benzylaminopurine (BAP; 1.00, 2.00 , and $4.00 \mathrm{mg} / \mathrm{L}$ ). The correlations among plantlet growth characteristics and plantlet survival rate after transplantation under field conditions were calculated. Increasing the NAA concentration increased the number of roots but reduced root length. The addition of AC enhanced shoot length and prevented the regeneration of dried-out, clustered, and abnormal shoots. Plantlets treated with $200 \mathrm{mg} / \mathrm{L}$ AC and $0.10 \mathrm{mg} / \mathrm{L}$ NAA produced the highest number of shoots, i.e., 4.1 shoots, which however, were shorter and lighter than those cultured with AC alone. Plantlets grown on medium supplemented with BAP showed no advantage in shoot number, shoot weight, plantlet surface area, or plantlet volume. The weight and shoot surface area of plantlets were strongly correlated. All plantlets grew well at 4 weeks post-transplantation. Overall, these results support this improved micropropagation method to regenerate robust ex vitro plantlets.
\end{abstract}

Keywords: dragon fruit; micropropagation; regeneration; spontaneous rooting; plant growth regulator

\section{Introduction}

Pitaya (Hylocereus spp.), which belongs to the family Cactaceae [1], has recently become an important fruit crop in Asia and America due to varietal improvements and increased production during the off-season using night-break/prolonged-daytime techniques [2-6]. H. polyrhizus 'Da Hong', also known as 'Big Red', is a red-fleshed pitaya cultivar and is the dominant cultivar grown in China, Vietnam, and Taiwan because of its desirable characteristics, including self-compatibility, large fruit size, high sweetness, and abundant yield $[3,6]$.

However, 'Da Hong' is susceptible to pathogenic infection [Cactus virus X [7], Neoscytalidium dimidiatum [8], and Colletotrichum spp. [9-11]] by penetrating hyphae or mechanical wounds $[7,12,13]$, reducing plant growth vigor, i.e., shoot initiation and flower blooming, and fruit production [9,12]. Agar-based micropropagation has proven to be a valuable method to decrease the risk of infection in tomatoes and cacti, as pathogenic contamination can be visually inspected and prevented [14-16]. Therefore, in vitro propagation may represent a potential strategy to reduce disease risk in 'Da Hong' plantlets and renew infected orchards. 
Plant state and environmental conditions during incubation affect pitaya tissue culture and the micro-propagules, including explant type, medium strength (Murashige and Skoog [MS]) [17], i.e., full- or $1 / 4$ strength, and the form and concentration of plant growth regulators (PGRs) $[14,18,19]$. Culture media are frequently supplemented with the PGRs naphthaleneacetic acid (NAA) and 6-benzylaminopurine (BAP) because of their availability, convenience, and direct shoot (cladode) regeneration properties [20]. Hylocereus plantlets cultured on media supplemented with these PGRs show a 2- to 18-fold increase in shoot regeneration rate compared with untreated micro-propagules, depending on the species and cultivars [18,21-25]. For example, plantlets of the white-fleshed pitaya $H$. undatus cultured on MS medium supplemented with appropriate PGRs, i.e., $4 \mathrm{mg} / \mathrm{L}$ BAP and 0.1 $\mathrm{mg} / \mathrm{L}$ NAA, regenerated a maximum of 22 shoots/plantlet; however, the shoot number of the control plantlets was unavailable [26]. Preliminary studies have proposed media for red-fleshed $H$. polyrhizus and its hybrids and reported an $83.2 \%$ in vitro germination rate and regeneration of $6-8$ shoots on the micro-propagules $[25,27,28]$. However, the specific cultivars used in these studies are unknown.

Few studies have reported normal regeneration in pitaya micropropagation [18,22]. Shoots regenerated using such PGRs were either semi-transparent or light green [21,28], indicating low shoot vigor, which prolonged the duration of micropropagation [14,29]. In addition, our preliminary results showed that the given media used for red-fleshed pitaya in previous studies were not appropriate for the 'Da Hong' cultivar, which produced abnormal shoots.

Activated charcoal (AC) plays a critical role in tissue cultures, promoting micropropagule growth and development. Wang and Huang [30] indicated that AC supplementation in the culture medium could darken the medium to simulate the soil conditions and absorb toxic metabolites, thereby increasing shoot and root development in Phalaenopsis, Cymbidium, and Dendrobium species. A reduction of residual PGR side effects in the explant rooting was also shown in Cactaceae species [31]. However, no AC benefit could be observed in shoot initiation in Vigna radiate [32] or root induction in Echinocactus, Echiaocereus, Mammillaria, and Stenocactus species [33].

Given the advantage of AC in reducing the side effects of PGRs during incubation and the potential to propagate an entire plantlet forming simultaneous shoots and roots from the primordium [32], MS medium supplemented with AC has been used for the micropropagation of white-fleshed pitaya [34]. Despite the importance of 'Da Hong' in the global pitaya industry, designated tissue culture studies of this cultivar are unavailable. The effects of AC on developing red-fleshed pitaya plantlets, particularly 'Da Hong', are thus unknown.

In the present study, in vitro segments of self-pollinating 'Da Hong' progeny were used as explants. To address the knowledge gap, we assessed the effects of AC in combination with different concentrations of PGRs on plantlet characteristics. We then analyzed the relationships among plantlet characteristics and their derivative parameters to construct an essential growth database for the red-fleshed pitaya tissue culture system. Finally, we improved the in vitro culture system based on an existing protocol [26]. The results of this study potentially provide a new in vitro propagation method for producing robust plantlets of $H$. polyrhizus 'Da Hong'.

\section{Materials and Methods}

\subsection{Plant Materials and Culture Establishment}

Self-pollinating fruits of $H$. polyrhizus 'Da Hong' were harvested from a commercial orchard in Taichung, central Taiwan $\left(24^{\circ} 14^{\prime} 33.2^{\prime \prime} \mathrm{N}, 120^{\circ} 48^{\prime} 21.6^{\prime \prime} \mathrm{E}\right)$, on 27 June 2019, 2 November 2019, and 11 July 2020. Seeds were collected from the flesh and sterilized following the method described by De Feria et al. [21], with modifications. In brief, the seeds were immersed in $75 \%(v / v)$ alcohol for $30 \mathrm{~s}$ and then in 1\% $(v / v)$ sodium hypochlorite containing Tween 20 for $15 \mathrm{~min}$. Next, the seeds were rinsed five times with sterile distilled water. The rinsed seeds were cultured in glass bottles with $1 / 4$ strength MS medium 
(M5519, Sigma Chemical Co., St. Louis, MO, USA) supplemented with 3\% (w/v) sucrose and $0.8 \%(w / v)$ agar (Kungfei Trading Co., Ltd., Tainan, Taiwan) to shorten by 1.5-fold the germination duration and increase their germination rate by $153 \%$ compared to fullstrength MS medium [35]. The cultures were incubated in a culture room at $25^{\circ} \mathrm{C} \pm 2{ }^{\circ} \mathrm{C}$ with a $16 / 8 \mathrm{~h}(\mathrm{~L} / \mathrm{D})$ photoperiod under $50 \mu \mathrm{mol} / \mathrm{m}^{2} / \mathrm{s}$ fluorescent light. Before use, the $\mathrm{pH}$ of the MS medium was adjusted to 5.8. All experiments were performed in the tissue culture laboratory of the Department of Horticulture at National Chung-Hsing University, Taichung, Taiwan.

\subsection{Shoot Regeneration and Root Induction Using $A C, N A A$, and BAP}

We investigated the effects of different concentrations and combinations of PGRs on shoot regeneration and root induction following a previous study [26], with modifications. Briefly, we supplemented the MS medium with either NAA alone $(0.05,0.10$, or $0.20 \mathrm{mg} / \mathrm{L}$; Sigma Chemical Co., St. Louis, MO, USA) or $200 \mathrm{mg} / \mathrm{L}$ AC in combination with NAA and BAP $(1.00,2.00$, and $4.00 \mathrm{mg} / \mathrm{L}$; Sigma Chemical Co., St. Louis, MO, USA) (Table 1).

Table 1. Experimental treatments of Murashige and Skoog (MS) medium supplemented with different combinations and concentrations of activated charcoal (AC) and plant growth regulators (PGRs).

\begin{tabular}{lccc}
\hline \multicolumn{2}{c}{ Treatment Label } & & PGRs ${ }^{\mathbf{1}} \mathbf{( \mathbf { m g } / \mathbf { L } )}$ \\
\hline NAA supplemented in MS medium & NAA & BAP \\
\hline CS & AC & - & - \\
TS01 & - & 0.05 & - \\
TS02 & - & 0.10 & - \\
TS03 & - & 0.20 & - \\
\hline AC, NAA, and BAP supplemented in MS medium & & BAP \\
& AC & NAA & - \\
\hline CM01 & - & - & - \\
CM02 & 200 & - & - \\
TM01 & 200 & 0.05 & 1.00 \\
TM02 & 200 & 0.05 & 2.00 \\
TM03 & 200 & 0.05 & - \\
TM04 & 200 & 0.05 & 1.00 \\
TM05 & 200 & 0.10 & 2.00 \\
TM06 & 200 & 0.10 & 4.00 \\
TM07 & 200 & 0.10 & - \\
TM08 & 200 & 0.10 & 1.00 \\
TM09 & 200 & 0.20 & 2.00 \\
TM10 & 200 & 0.20 & 4.00 \\
TM11 & 200 & 0.20 & \\
TM12 & 200 & 0.20 & \\
\hline
\end{tabular}

${ }^{1}$ NAA, $\alpha$-naphthaleneacetic acid; BAP, 6-benzylaminopurine.

Activated charcoal was added to the MS medium supplemented with BAP as the preliminary results showed that shoots regenerated using the MS medium supplemented with BAP without AC dried out, clustered, and became abnormal (Figure 1). We found that adding $200 \mathrm{mg} / \mathrm{L}$ of $\mathrm{AC}$ into the medium reduced these side effects. The in vitro pitaya seedlings were excised and sub-cultured as mother explants. The shoots regenerated by the mother plants were excised as $15 \mathrm{~mm}$ segments. Three replicate bottles, each containing five segments, were prepared for each treatment. 

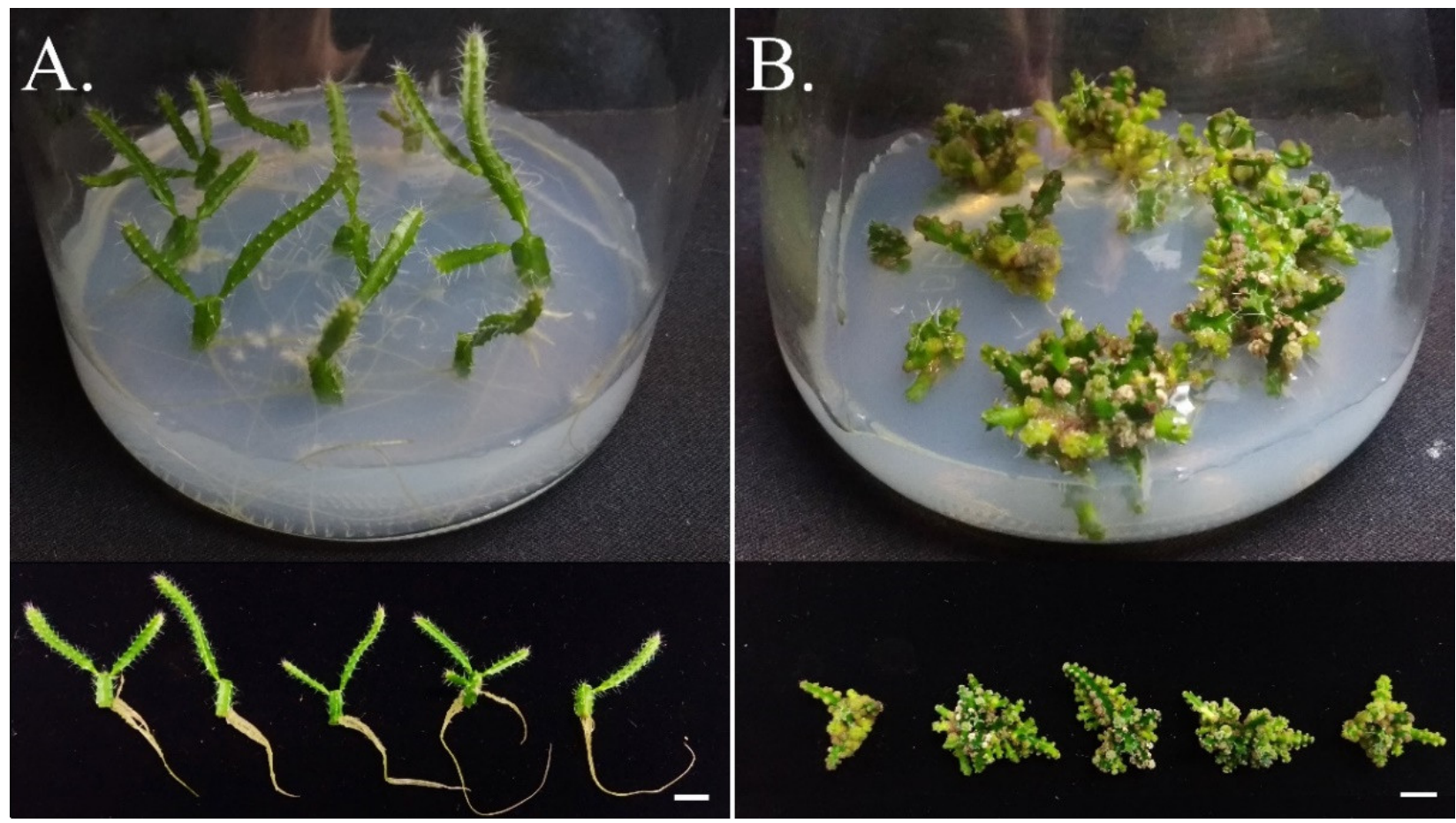

Figure 1. In vitro plantlets of Hylocereus polyrhizus 'Da Hong' after 5 months of incubation (A) on Murashige and Skoog (MS) medium and (B) with $2.00 \mathrm{mg} / \mathrm{L}$ 6-benzylaminopurine (BAP). Scale Bar $=1 \mathrm{~cm}$ for the plantlets without agar.

Plantlet growth characteristics (i.e., number of shoots, shoot length, root length, and shoot surface area) were measured using ImageJ [36]. Owing to the irregular size and shape of the plantlet shoots, it was difficult to accurately calculate the shoot surface area. In our best effort to measure the full surface area, four sides of the plantlet shoots were photographed, and the photos were transformed into an 8-bit type followed by selection of software functions (i.e., threshold and filter) to match the shape of the shoots. The plantlets were weighed (FW) using an electronic balance (XT220A, Precisa Gravimetrics AG, Dietikon, Switzerland) after 8 weeks of incubation. Archimedes' principle was applied to measure the shoot volume. The shoot surface area per unit length [SAL; mm; Surface area shoots $\left(\mathrm{mm}^{2}\right) /$ Length shoots $\left.(\mathrm{mm})\right]$, shoot weight per unit length [SWL; $\mathrm{mg} \mathrm{FW} / \mathrm{mm}$; $\mathrm{FW}_{\text {shoots }}(\mathrm{mg}) /$ Length shoots $(\mathrm{mm})$ ], root weight per unit length [RWL; $\mathrm{mg} \mathrm{FW} / \mathrm{mm} ; \mathrm{FW}$ roots $(\mathrm{mg}) /$ Length main root $(\mathrm{mm})]$, and root/shoot ratio [g FW/g FW; FW roots $(\mathrm{g} \mathrm{FW}) / \mathrm{FW}$ shoots (g FW)] were also calculated, where FW indicated fresh weight. Finally, we analyzed the pairwise Pearson's correlations between plantlet growth characteristics to construct the essential growth database of red-fleshed pitaya in vitro, e.g., the relationship between plantlet weight and surface area and the relationship between (regeneration) shoot length and (regeneration) shoot surface area.

\subsection{Acclimatization}

After 8 weeks of incubation in the culture room (on 25 April 2020), plantlets were transferred from the bottle, and the agar was gently removed from the roots. The ex vitro plantlets were maintained in a plastic box containing clean water at room temperature $\left(22-25^{\circ} \mathrm{C}\right)$ with a $16 / 8 \mathrm{~h}(\mathrm{~L} / \mathrm{D})$ photoperiod under $50 \mu \mathrm{mol} / \mathrm{m}^{2} / \mathrm{s}$ fluorescent light for 1 week. The plantlets were then planted in plastic pots containing peat soil ( $\mathrm{pH}$ 5.5-6.0, Stender Peat Substrate, Known-You Seed Co., Ltd., Dashu, Kaohsiung, Taiwan). The plantlets were cultured on the terrace under field conditions with $80 \mu \mathrm{mol} / \mathrm{m}^{2} / \mathrm{s}$ solar light for 4 weeks, and the plantlet survival rate was then assessed. 


\subsection{Data Analysis and Statistics}

Data were analyzed using one-way ANOVA in SAS 9.4 (SAS Institute Inc., Cary, NC, USA). The PROC GLM procedure was used to conduct multiple pairwise comparisons using Fisher's protected least significance difference (LSD) test. We considered $p \leq 0.05$ as significant. Figures were constructed using SigmaPlot 10.0 (Systat Software Inc., San Jose, CA, USA) and Powerpoint 2019 (Microsoft Corp., Redmond, WA, USA). A heat map of Pearson's correlation coefficients between pairs of plantlet growth characteristics was created using Python 3.8.0 (Python Software Foundation).

\section{Results}

\subsection{Effects of NAA Alone on Shoot Regeneration and Root Induction}

H. polyrhizus 'Da Hong' plantlets grown on MS medium supplemented with various concentrations of NAA are shown in Figure S1. For all concentrations of NAA, there were no significant differences in the shoot regeneration number (3.6 shoots/plantlet), shoot length $(57.32 \mathrm{~mm})$, and average shoot length $(18.41 \mathrm{~mm}$; Figure 2$)$. Other plantlet growth characteristics, i.e., plantlet weight (Figure S2), plantlet surface area, and plantlet volume (data not shown), were similar for all different concentrations of NAA.

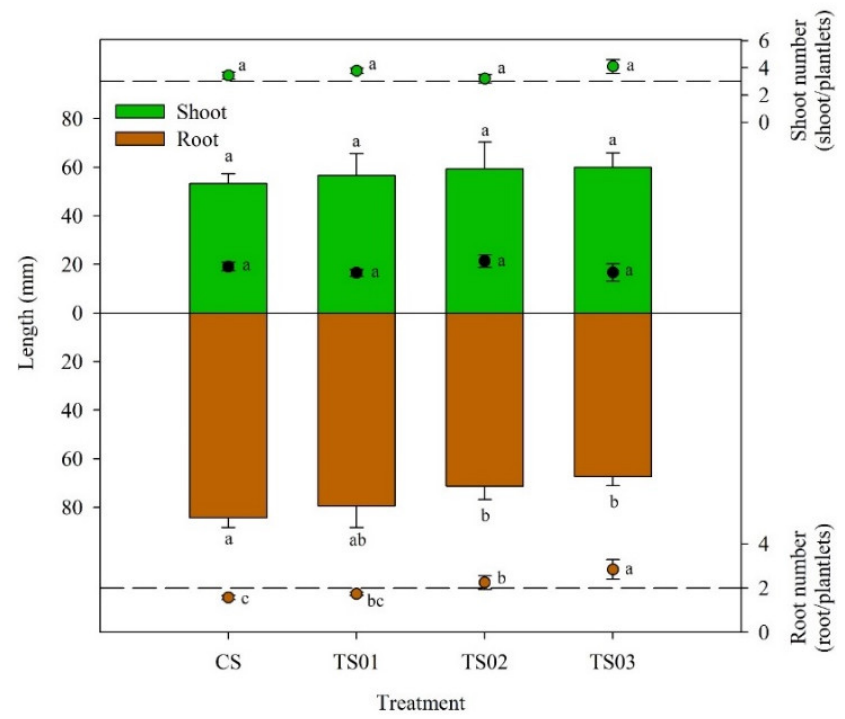

Figure 2. Shoot regeneration number, root induction number, and length of shoots and roots of Hylocereus polyrhizus 'Da Hong' grown on Murashige and Skoog (MS) medium supplemented with $\alpha$-naphthaleneacetic acid (NAA) alone. Treatments: CS, control; TS01, $0.05 \mathrm{mg} / \mathrm{L}$ NAA; TS02, $0.10 \mathrm{mg} / \mathrm{L}$ NAA; TS03, $0.20 \mathrm{mg} / \mathrm{L}$ NAA. Mean $\pm \mathrm{SE}(n=3,5$ segments per replicate). Means followed by different letters near the column and circle are significantly different at $p=0.05$ using Fisher's protected LSD test. The black circle inside the green column indicates the average shoot length.

Plantlets grown on the culture medium supplemented with $0.20 \mathrm{mg} / \mathrm{L}$ NAA (treatment TS03) had significantly ( $p=0.0024)$ more roots ( 2.8 roots/plantlet) than plantlets grown on medium supplemented with $0,0.05$, or $0.10 \mathrm{mg} / \mathrm{L}$ NAA $(1.6,1.7$, and 2.2 roots/plantlet, respectively; Figure 2). However, plantlets grown on control culture medium (treatment CS) had significantly longer main roots $(84.38 \mathrm{~mm})$ than those grown on media supplemented with 0.10 and $0.20 \mathrm{mg} / \mathrm{L}$ NAA treatments (71.32 and $67.47 \mathrm{~mm}$, respectively); plantlets grown on control culture medium also had longer main roots than plantlets grown on culture medium supplemented with $0.05 \mathrm{mg} / \mathrm{L}$ NAA $(79.40 \mathrm{~mm})$, but this difference was not significant. Root weight per unit length was significantly greater in plantlets grown on 
medium supplemented with $0.20 \mathrm{mg} / \mathrm{L} \mathrm{NAA}(1.09 \mathrm{mg} / \mathrm{mm})$ than in plantlets grown on control medium (0.52 mg/mm; Figure 3).

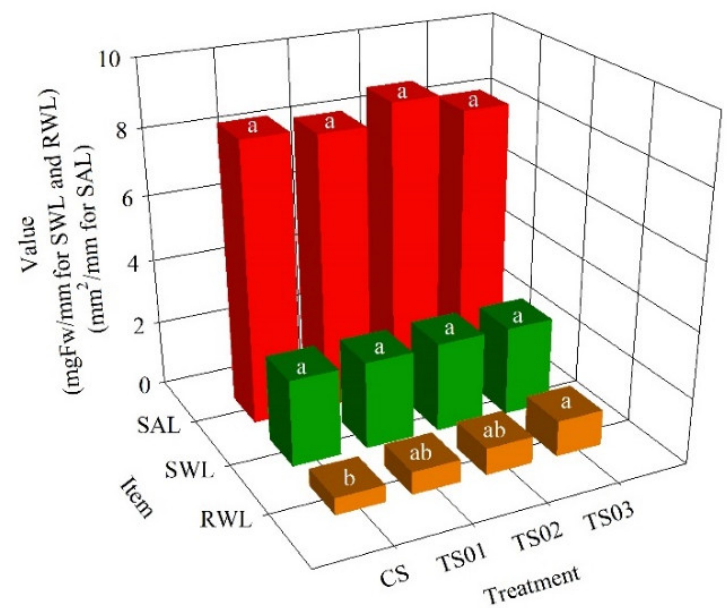

Figure 3. Plantlet growth characteristics of shoot surface area per unit length (SAL; surface area shoots/Length shoots), shoot weight per unit length (SWL; FW shoots/Length shoots), and root weight per unit length (RWL; FW roots/Length main root) of Hylocereus polyrhizus 'Da Hong' grown on Murashige and Skoog (MS) medium supplemented with $\alpha$-naphthaleneacetic acid (NAA) alone. Treatments: CS, control; TS01, $0.05 \mathrm{mg} / \mathrm{L}$ NAA; TS02, $0.10 \mathrm{mg} / \mathrm{L}$ NAA; TS03, $0.20 \mathrm{mg} / \mathrm{L}$ NAA. Mean $\pm \mathrm{SE}(n=3$, 5 segments per replicate). Means followed by different letters near the column are significantly different at $p=0.05$ using Fisher's protected LSD test.

\subsection{The Combined Effects of $A C, N A A$, and BAP on Shoot Regeneration and Root Induction}

Shoot appearance was improved by supplementing the MS medium with $200 \mathrm{mg} / \mathrm{L}$ AC: the shoots of plantlets grown on AC-supplemented media were dark green, with a succulent structure (Figure 4). The plantlets grown on medium supplemented with AC and $0.10 \mathrm{mg} / \mathrm{L}$ NAA (TM05-08) regenerated significantly more shoots (4.1 shoots/plantlet) than plantlets grown on any other media (Figure $5 \mathrm{~A}$ ).

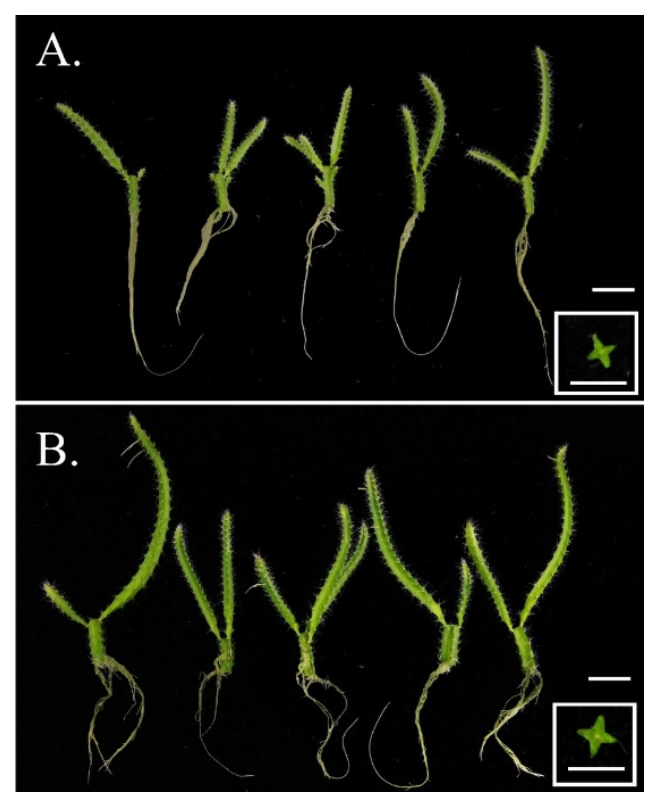

Figure 4. Plantlets of Hylocereus polyrhizus 'Da Hong' cultured (A) on Murashige and Skoog (MS) medium and (B) on activated charcoal (AC)-supplemented MS medium. Profiles in the white square frame are plantlet transections, showing that plantlets grown on the AC-supplemented MS medium were succulent. Bar $=2 \mathrm{~cm}$; bar inside white square $=1 \mathrm{~cm}$. 
A

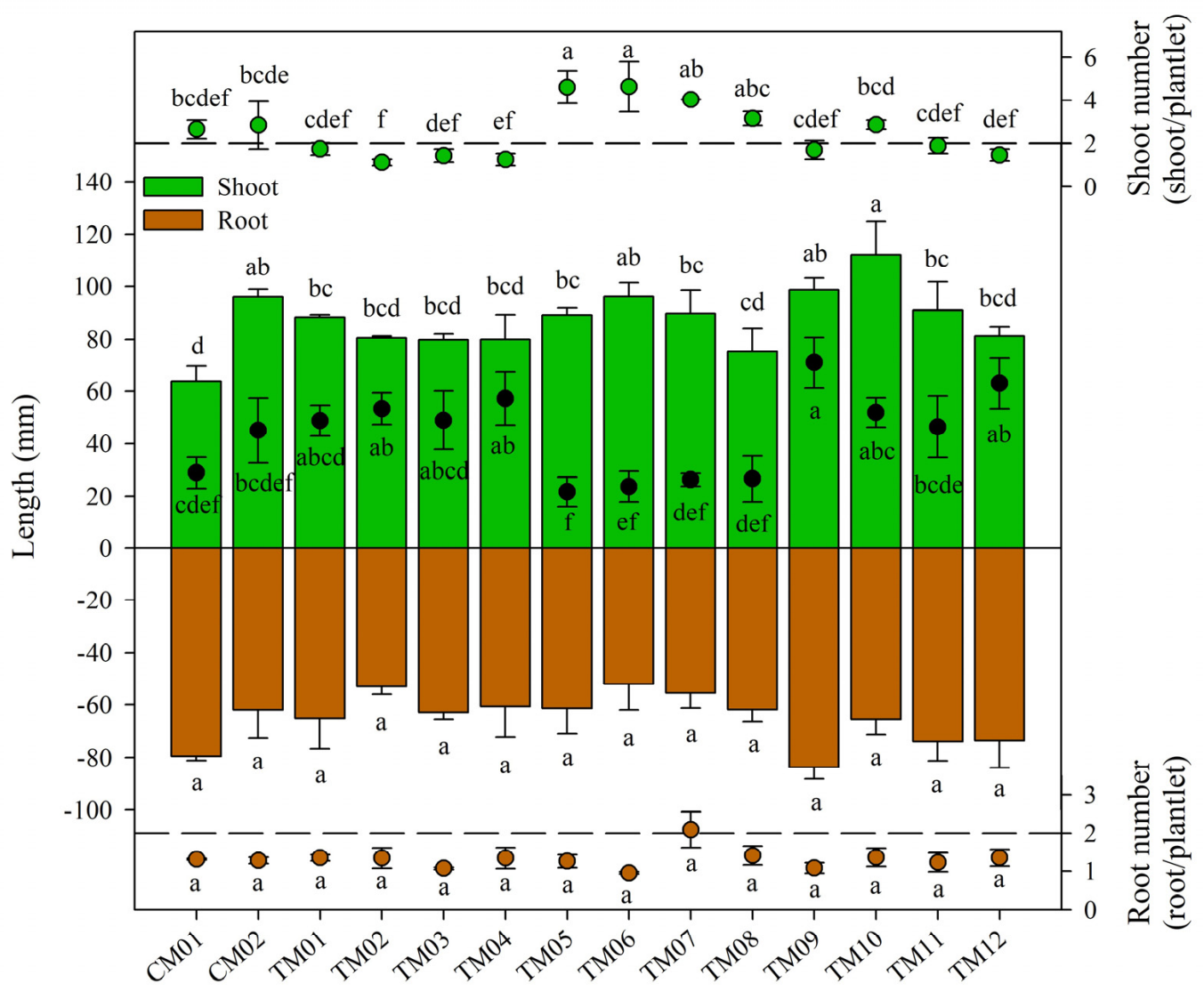

Treatment

B

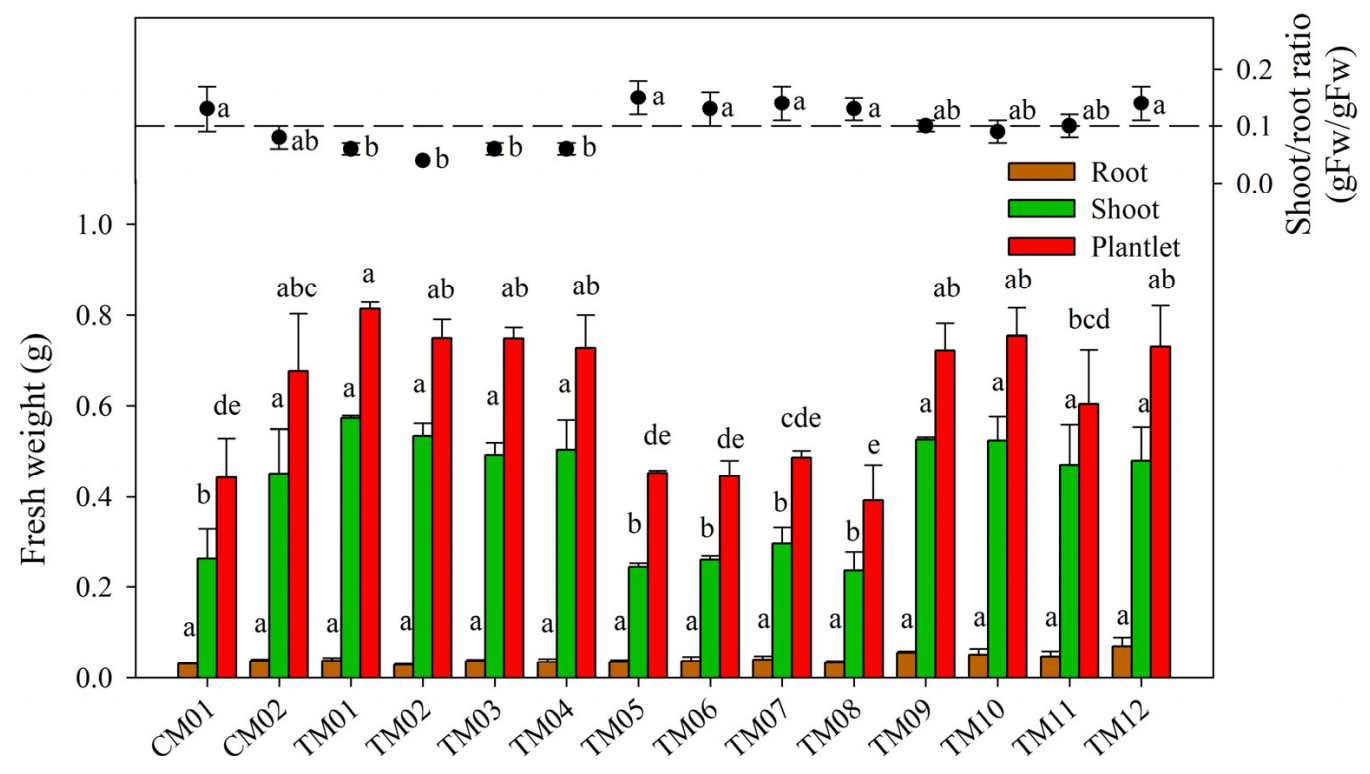

Treatment

Figure 5. Shoot regeneration number, root induction number, and shoot and root lengths (A); fresh weight of plantlets, shoots, and roots, as well as root/shoot ratio (B) of Hylocereus polyrhizus 'Da Hong' 
cultured on Murashige and Skoog (MS) medium supplemented with activated charcoal (AC) combined with $\alpha$-naphthaleneacetic acid (NAA) and 6-benzylaminopurine (BAP). The black circle inside the green column in plate A indicates the average shoot length. Treatments: CM01, control; CM02, $200 \mathrm{mg} / \mathrm{L} \mathrm{AC;}$ TM01, $200 \mathrm{mg} / \mathrm{L}$ AC and $0.05 \mathrm{mg} / \mathrm{L}$ NAA; TM02, $200 \mathrm{mg} / \mathrm{L} \mathrm{AC}, 0.05 \mathrm{mg} / \mathrm{L}$ NAA, and $1.00 \mathrm{mg} / \mathrm{L}$ BAP; TM03, $200 \mathrm{mg} / \mathrm{L}$ AC, $0.05 \mathrm{mg} / \mathrm{L}$ NAA, and $2.00 \mathrm{mg} / \mathrm{L}$ BAP; TM04, $200 \mathrm{mg} / \mathrm{L} \mathrm{AC,} 0.05 \mathrm{mg} / \mathrm{L}$ NAA, and $4.00 \mathrm{mg} / \mathrm{L}$ BAP; TM05, $200 \mathrm{mg} / \mathrm{L}$ AC and $0.10 \mathrm{mg} / \mathrm{L}$ NAA; TM06, $200 \mathrm{mg} / \mathrm{L} \mathrm{AC,} 0.10 \mathrm{mg} / \mathrm{L}$ NAA, $1.00 \mathrm{mg} / \mathrm{L}$ BAP; TM07, $200 \mathrm{mg} / \mathrm{L}$ AC, $0.10 \mathrm{mg} / \mathrm{L} \mathrm{NAA}$, and $2.00 \mathrm{mg} / \mathrm{L} \mathrm{BAP;} \mathrm{TM08,} 200 \mathrm{mg} / \mathrm{L} \mathrm{AC}$, $0.10 \mathrm{mg} / \mathrm{L}$ NAA, and $4.00 \mathrm{mg} / \mathrm{L}$ BAP; TM09, $200 \mathrm{mg} / \mathrm{L}$ AC and $0.20 \mathrm{mg} / \mathrm{L}$ NAA; TM10, $200 \mathrm{mg} / \mathrm{L}$ AC, $0.20 \mathrm{mg} / \mathrm{L}$ NAA, and $1.00 \mathrm{mg} / \mathrm{L}$ BAP; TM11, $200 \mathrm{mg} / \mathrm{L} \mathrm{AC}, 0.20 \mathrm{mg} / \mathrm{L} \mathrm{NAA}$, and $2.00 \mathrm{mg} / \mathrm{L}$ BAP; $\mathrm{TM} 12,200 \mathrm{mg} / \mathrm{L}$ AC, $0.20 \mathrm{mg} / \mathrm{L}$ NAA, and $4.00 \mathrm{mg} / \mathrm{L}$ BAP. Mean $\pm \mathrm{SE}$ ( $n=3,5$ segments per replicate). Means associated with different letters near the columns are significantly different at $p=0.05$ using Fisher's protected LSD test.

The shoot lengths of plantlets grown under the treatment conditions CM02, TM06, TM09, and TM10 were significantly longer $(93.97 \mathrm{~mm})$ than those grown under other treatment conditions (63.81-90.96 mm; Figure 5A). The average shoot lengths were significantly greater in treatments TM01-04, TM09, TM10, and TM12 (70.93 mm) compared to those obtained with the controls and other treatments (21.71-46.50 mm; Figure 5A). The addition of $1.00 \mathrm{mg} / \mathrm{L}$ BAP tended to increase shoot length, especially in combination with 0.10 and $0.20 \mathrm{mg} / \mathrm{L}$ NAA (i.e., TM06 and TM10), although plantlets had similar shoot lengths in medium supplemented with AC alone. However, the average shoot lengths were low for plantlets cultured on $0.10 \mathrm{mg} / \mathrm{L}$ NAA, due to the influence of NAA concentration on the shoot number.

Plantlets grown on medium supplemented with 0.05 or $0.20 \mathrm{mg} / \mathrm{L}$ NAA had shoots of similar weight to those in treatment CM02 (MS medium supplemented with AC only); shoot weight in these groups was significantly greater than that of plantlets grown on $0.10 \mathrm{mg} / \mathrm{L}$ NAA (Figure 5B). In addition, plantlet surface area and plantlet volume were similar across plantlets grown on media supplemented with AC alone (CM02) and AC in combination with $0.05 \mathrm{mg} / \mathrm{L}$ NAA or $0.20 \mathrm{mg} / \mathrm{L} \mathrm{NAA}$; these values were significantly higher than those obtained with CM01 and the treatments with $0.10 \mathrm{mg} / \mathrm{L} \mathrm{NAA}$ (Figure 6A). Neither plantlet surface area nor plantlet volume was affected by BAP concentrations (Figure 6A).

Both SWL and SAL were significantly affected by NAA and AC: shoots grown on medium supplemented with AC only (CM02) or medium supplemented with AC in combination with 0.05 or $0.20 \mathrm{mg} / \mathrm{L}$ NAA had a heavier SWL and larger SAL than shoots grown on medium supplemented with $0.10 \mathrm{mg} / \mathrm{L}$ NAA (Figure 6B).

The root number of the plantlets remained similar (1.3 roots/plantlet) across all combinations of PGR supplements (Figure 5A). Main root length and root weight were also similar across PGR treatments (Figure 5A,B). Irrespective of segment weight, the root/shoot ratios of treatments TM01-04 (0.05 mg/L NAA with 0-4.00 mg/L BAP) were lower than those of CM01 and of treatments TM05-08 and TM12 (0.10-0.20 mg/L NAA with 0-4.00 mg/L BAP; Figure 5B). Notably, the addition of BAP did not affect plantlet fresh weight or root/shoot ratio. 
A

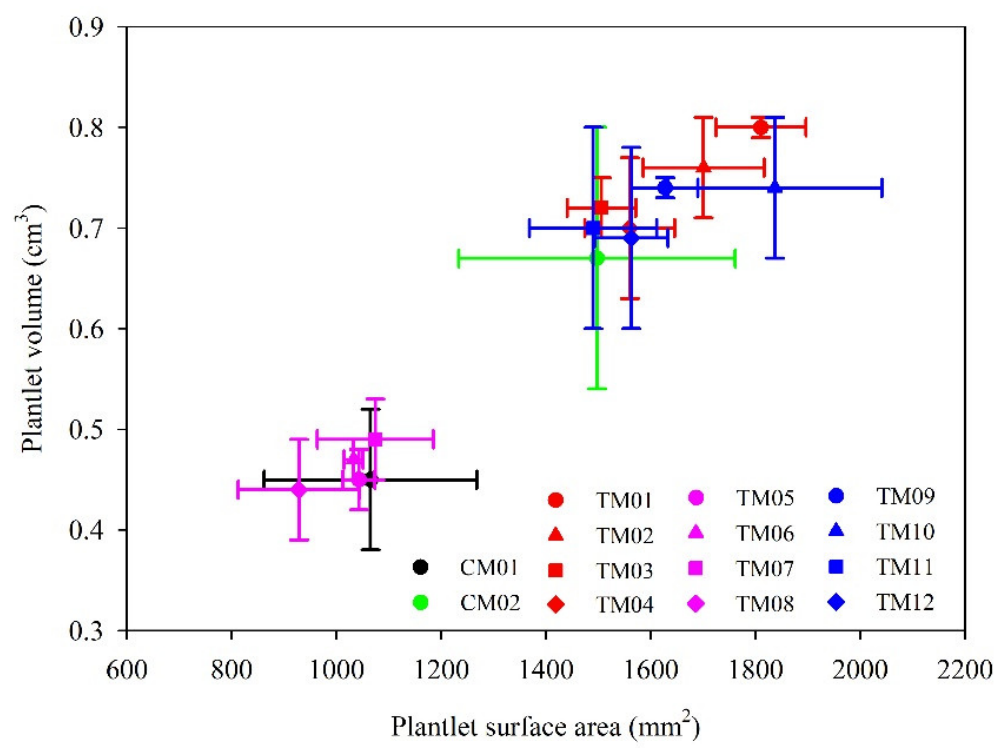

B

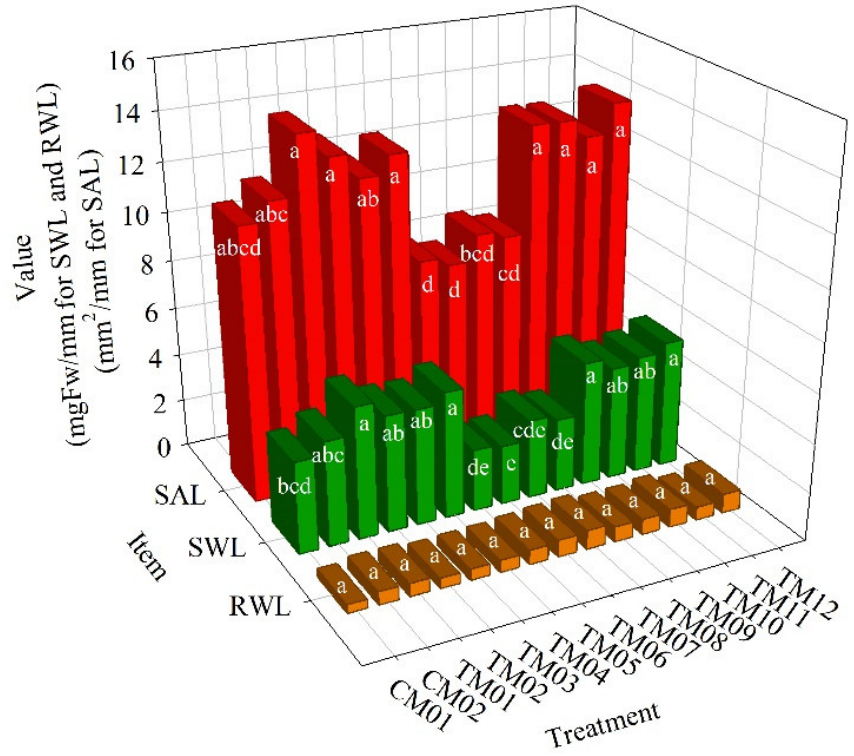

Figure 6. Relationship between plantlet surface area and plantlet volume (A) and shoot surface area per

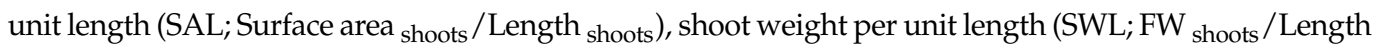
shoots), and root weight per unit length (RWL; FW roots/Length main root) (B) of Hylocereus polyrhizus 'Da Hong' cultured on Murashige and Skoog (MS) medium supplemented with activated charcoal (AC) combined with $\alpha$-naphthaleneacetic acid (NAA) and 6-benzylaminopurine (BAP). Treatments: CM01, control; CM02, $200 \mathrm{mg} / \mathrm{L}$ AC; TM01, $200 \mathrm{mg} / \mathrm{L}$ AC and $0.05 \mathrm{mg} / \mathrm{L} \mathrm{NAA}$; TM02, $200 \mathrm{mg} / \mathrm{L} \mathrm{AC}$, $0.05 \mathrm{mg} / \mathrm{L} \mathrm{NAA}$, and $1.00 \mathrm{mg} / \mathrm{L}$ BAP; TM03, $200 \mathrm{mg} / \mathrm{L} \mathrm{AC}, 0.05 \mathrm{mg} / \mathrm{L}$ NAA, and $2.00 \mathrm{mg} / \mathrm{L}$ BAP; TM04, $200 \mathrm{mg} / \mathrm{L}$ AC, $0.05 \mathrm{mg} / \mathrm{L}$ NAA, and $4.00 \mathrm{mg} / \mathrm{L}$ BAP; TM05, $200 \mathrm{mg} / \mathrm{L}$ AC and $0.10 \mathrm{mg} / \mathrm{L} \mathrm{NAA}$; TM06, $200 \mathrm{mg} / \mathrm{L}$ AC, $0.10 \mathrm{mg} / \mathrm{L}$ NAA, $1.00 \mathrm{mg} / \mathrm{L}$ BAP; TM07, $200 \mathrm{mg} / \mathrm{L}$ AC, $0.10 \mathrm{mg} / \mathrm{L} \mathrm{NAA}$, and $2.00 \mathrm{mg} / \mathrm{L}$ BAP; TM08, $200 \mathrm{mg} / \mathrm{L}$ AC, $0.10 \mathrm{mg} / \mathrm{L}$ NAA, and $4.00 \mathrm{mg} / \mathrm{L}$ BAP; TM09, $200 \mathrm{mg} / \mathrm{L}$ AC and $0.20 \mathrm{mg} / \mathrm{L}$ NAA; TM10, $200 \mathrm{mg} / \mathrm{L}$ AC, $0.20 \mathrm{mg} / \mathrm{L}$ NAA, and $1.00 \mathrm{mg} / \mathrm{L}$ BAP; TM11, $200 \mathrm{mg} / \mathrm{L}$ AC, $0.20 \mathrm{mg} / \mathrm{L}$ NAA, and $2.00 \mathrm{mg} / \mathrm{L}$ BAP; TM12, $200 \mathrm{mg} / \mathrm{L}$ AC, $0.20 \mathrm{mg} / \mathrm{L} \mathrm{NAA}$, and $4.00 \mathrm{mg} / \mathrm{L}$ BAP. Mean $\pm \operatorname{SE}(n=3,5$ segments per replicate). Means associated with different letters near the columns are significantly different at $p=0.05$ using Fisher's protected LSD test. 


\subsection{Pairwise Correlations between Growth Characteristics of Shoots and Roots}

There were no strong correlations between shoot number, root number, and other growth characteristics (Figure 7). However, the shoot lengths of the plantlets were significantly correlated with plantlet surface area $(\mathrm{r}=0.647 ; p=0.0001)$, and plantlet weight was significantly correlated with plantlet surface area and plantlet volume $(\mathrm{r}=0.931$ and 0.986 , respectively; $p=0.0001$ ). A high regression coefficient of 0.9795 was found between regeneration shoot length and surface area (Figure 8A), which coincided with the regression results for plantlet surface area and plantlet volume based on plantlet weight, which were 0.8665 and 0.9767 , respectively (Figure 8B,C). Given the intricate measurements of micro-propagules surface area and volume, the regression results provide a well-calculated basis (plantlet weight) for exploring growth characteristics in vitro.

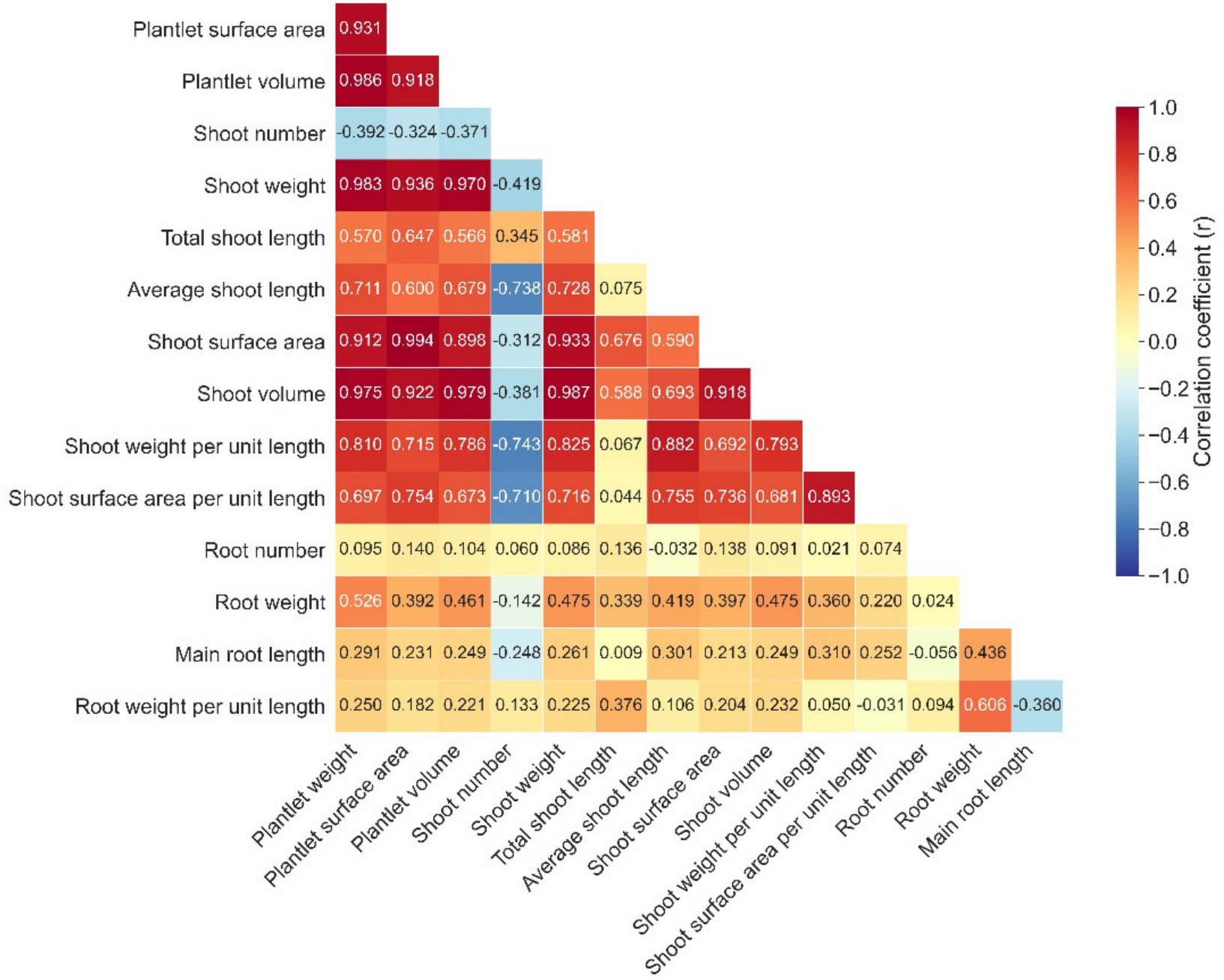

Figure 7. Heat map of Pearson's correlation coefficients for in vitro plantlet growth characteristics of Hylocereus polyrhizus 'Da Hong' incubated in a culture room at $25^{\circ} \mathrm{C} \pm 2{ }^{\circ} \mathrm{C}$ with a $16 / 8 \mathrm{~h}$ (L/D) photoperiod under $50 \mu \mathrm{mol} / \mathrm{m}^{2} / \mathrm{s}$ fluorescent light. 

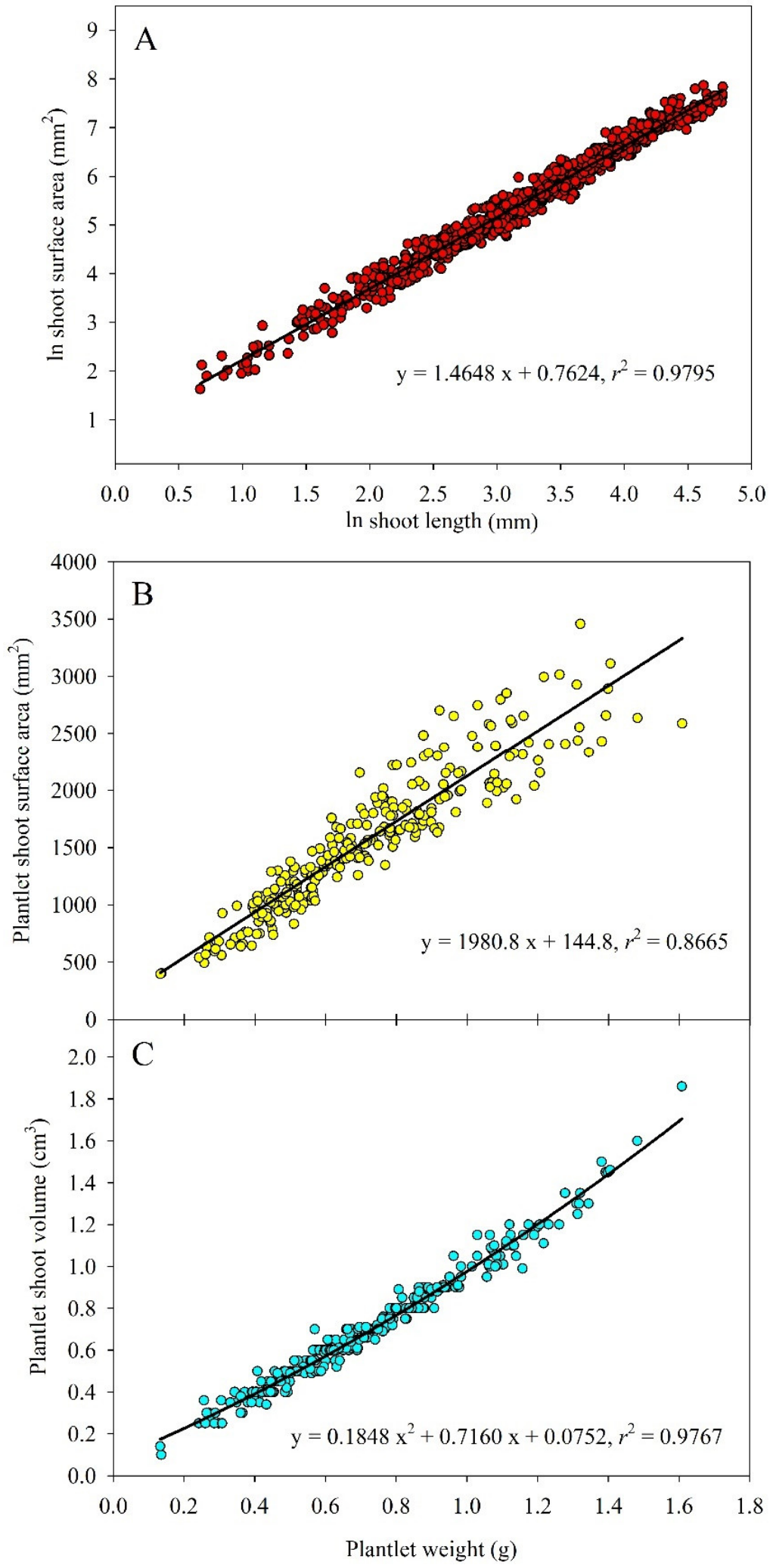

Figure 8. Relationships (A) between (regeneration) shoot surface area and (regeneration) shoot length, (B) between plantlet weight and plantlet surface area, and (C) between plantlet weight and plantlet volume on Hylocereus polyrhizus 'Da Hong'. The regression equations were: (A) $\mathrm{y}=1.4648 \mathrm{x}+0.7624$ $\left(n=808, r^{2}=0.9795, p<0.0001\right),(\mathbf{B}) \mathrm{y}=1980.8 \mathrm{x}+144.8\left(n=270, r^{2}=0.8665, p<0.0001\right),(\mathbf{C}) \mathrm{y}=0.1848 \mathrm{x}^{2}$ $+0.7160 x+0.0752\left(n=270, r^{2}=0.9767, p<0.0001\right)$, respectively. 


\subsection{Cultivated Duration and Acclimatization}

Segments excised from the in vitro seedlings regenerated new shoots after 1 week of incubation, irrespective of PGR supplementation. Micro-propagules were transplanted to the field after 4 weeks of in vitro incubation when the shoots were $4 \mathrm{~cm}$ long. None of the plantlets died or showed signs of pathogenic infection during the 4 weeks of field cultivation (Figure 9).
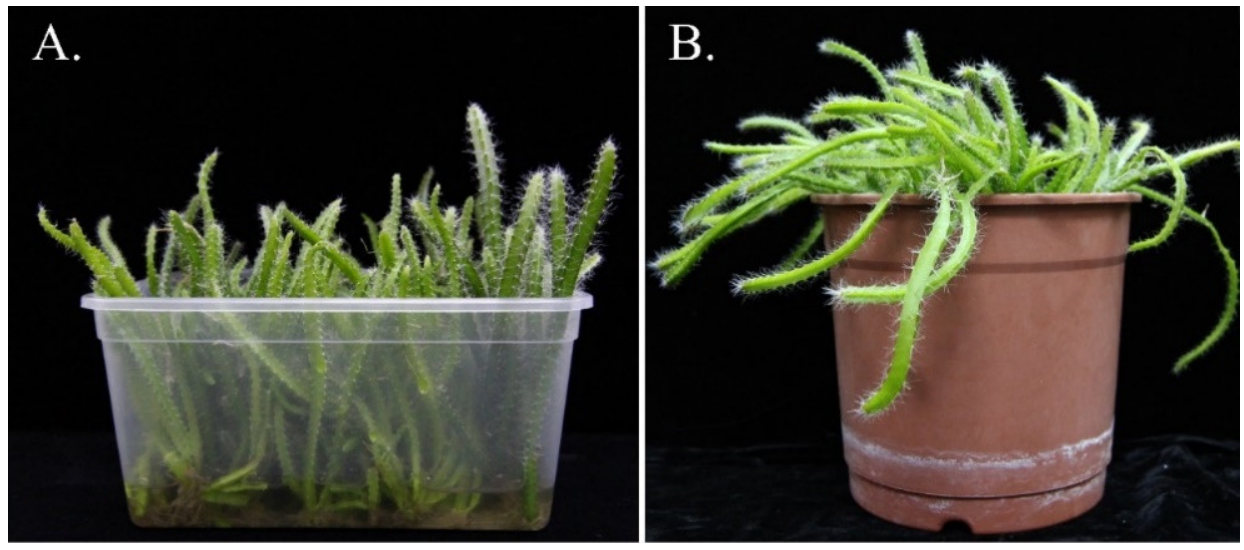

Figure 9. Acclimatization of Hylocereus polyrhizus 'Da Hong' at room temperature $\left(22-25{ }^{\circ} \mathrm{C}\right)$. (A) Plantlets hardened by incubating in water, (B) all plantlets grew well at 4 weeks after transplantation.

\section{Discussion}

\subsection{Effects of NAA Alone on Shoot Regeneration and Root Induction}

Micro-propagules growth qualities were affected by the concentrations and combinations of PGRs [14,19] and endogenous hormones [37] in the culture medium. The shoot regeneration number of 'Da Hong' pitaya was not affected by single PGR NAA supplementation, in contrast with previous observations of Mammillaria san-angelensis (Cactaceae) [38], wherein NAA supplementation increased the number of shoots per explant. The benefits of BAP on in vitro shoot sprouting and development have been reported for certain Cactaceae [37] and Hylocereus species [39]. However, BAP supplementation might cause hormonal imbalance in plants. Indeed, supplementation with $>1.00 \mathrm{mg} / \mathrm{L}$ BAP produced compact, dried-out shoots in 'Da Hong' pitaya in the present study. Our results demonstrate that the Hylocereus plantlet response to BAP might be species-specific.

'Da Hong' produced 1.6 roots per plantlet in PGR-free culture medium, consistent with previous results in $H$. costaricensis [39] and other Cactaceae species [38,40,41]. However, root length decreased as the number of roots increased, e.g., for treatment TS03, in contrast to previous observations in H. undatus [24]. In addition, root density (RWL) was significantly greater in plantlets cultured on medium supplemented with $0.20 \mathrm{mg} / \mathrm{L}$ NAA than in those cultured on PGR-free medium. These results suggest that, in 'Da Hong', the length of the primary adventitious roots decreased, whereas the number/lengths of the lateral roots increased when NAA concentration increased in the culture medium. After exposure to excessively high levels of NAA, this may occur due to root tip enlargement [42] or the synthesis of inappropriate PGRs $[43,44]$. Both processes would subsequently reduce the vigor and viability of micro-plants [42]. Thus, it is critical to identify appropriate NAA concentrations for optimal healthy root growth in 'Da Hong' pitaya plantlets.

\subsection{The Combined Effects of $A C, N A A$, and BAP on Shoot Regeneration and Root Induction}

The addition of $A C$ is known to promote plantlet growth and development [30] and spontaneous rooting during micropropagation [34]. Activated charcoal supplementation facilitated in vitro organogenesis by absorbing the excess substrates and providing a dark environment to simulate soil conditions [30]. AC-related sucrose hydrolysis eased micropropagule use $[45,46]$. Moreover, AC promoted both nitrate and ammonium uptake under 
tissue culture conditions, which facilitated plantlet development [32]. Consistent with this, 'Da Hong' pitaya plantlets grown on medium supplemented with AC exhibited remarkable improvement in several characteristics, including shoot length, shoot weight, shoot surface area, and shoot volume. It is, therefore, possible that AC promotes micro-shoot maturation and accelerates the propagation cycle by increasing shoot length and weight.

The maximum shoot number for regenerated 'Da Hong' (4.1 shoots/plantlet) could be observed in plantlets cultured on medium supplemented with $200 \mathrm{mg} / \mathrm{L} \mathrm{AC}$ and $0.10 \mathrm{mg} / \mathrm{L}$ NAA. This result corresponded to 2.4 -fold more shoots (1.7 shoots/plantlet) than those regenerated on medium containing $200 \mathrm{mg} / \mathrm{L}$ AC combined with 0.05 or $0.20 \mathrm{mg} / \mathrm{L}$ NAA and to 1.5-fold more shoots (2.8 shoots/plantlet) than those regenerated on MS medium containing $200 \mathrm{mg} / \mathrm{L}$ AC only. However, the shoot regeneration number (2.6 shoots/plantlet) of 'Da Hong' was 1.4-fold higher on PGR-free MS medium than on MS medium supplemented with multiple PGRs, i.e., $200 \mathrm{mg} / \mathrm{L}$ AC, $0.20 \mathrm{mg} / \mathrm{L}$ NAA, and $2.00 \mathrm{mg} / \mathrm{L}$ BAP. This result was inconsistent with the observation in red/purple-fleshed pitaya $H$. purpusii, in which plantlets produced 5.3-fold more shoots on MS medium supplemented with $0.20 \mathrm{mg} / \mathrm{L}$ NAA and $2.00 \mathrm{mg} / \mathrm{L}$ BAP than on PGR-free MS medium [21].

Compared to the shoot regeneration results for red-fleshed 'Da Hong' pitaya, plantlets of the white-fleshed pitaya $H$. undatus regenerated 2.2-fold more shoots (2.2 shoots / plantlet) on MS medium supplemented with $1000 \mathrm{mg} / \mathrm{L}$ AC combination with $0.10 \mathrm{mg} / \mathrm{L}$ NAA and $4.00 \mathrm{mg} / \mathrm{L} \mathrm{BAP} \mathrm{[34]} \mathrm{and} \mathrm{18-fold} \mathrm{more} \mathrm{shoots} \mathrm{(18} \mathrm{shoots/plantlet)} \mathrm{on} \mathrm{MS} \mathrm{medium}$ supplemented with $0.01 \mathrm{mg} / \mathrm{L}$ NAA and $2.50 \mathrm{mg} / \mathrm{L}$ BAP [18] than plantlets grown on PGR-free MS medium (1.0 shoot/plantlet) [24].

Although AC supplementation had several advantages, the negative effects on the non-selective absorption of substances including PGRs should also be considered [32]. The NAA and BAP concentrations used in the present study were similar to those indicated in a previous report [34], but the regeneration number of 'Da Hong' pitaya was higher in combination with $200 \mathrm{mg} / \mathrm{L} \mathrm{AC}$ than that of white-fleshed pitaya grown in $1000 \mathrm{mg} / \mathrm{L}$ AC. Despite the genetic differentiation in species and cultivars, PGR absorption by AC might be a reason behind the reduction in plantlet shoot initiation and regeneration, i.e., the shoot regeneration number of plantlets was higher in AC-free media than in low-AC concentration media, while the media supplemented with AC in high concentration exhibited smaller shoot numbers. PGR concentration after AC supplementation in the culture medium would require investigation, confirming the quality and quantity of medium substances and improving the culture medium.

Consistent with a previous study reporting that similar shoot lengths $(18.5 \mathrm{~mm})$ were observed after treatment with varied BAP concentrations [39], our results indicated that BAP supplementation did not affect the average shoot length, considering the shoot number. However, NAA concentration did influence shoot development in 'Da Hong' pitaya, with the average shoot length increasing by 3.21-18.5 mm compared to $H$. costaricensis [39]. NAA supplementation had similar beneficial effects on other shoot characteristics, including weight, surface area, volume, SWL, and SAL. These results are consistent with those of Mauseth and Halperin [37], who suggested that NAA suppresses the effect of BAP on plantlet development and that the types and concentrations of PGRs used affect plantlet organogenesis during tissue culture.

\subsection{Pairwise Correlations between Growth Characteristics of Shoots and Roots}

Studies on the relationships among plantlet growth characteristics are rare in the genus Hylocereus. However, for Opuntia ficus-indica, which is another plant of Cactaceae, shoot weight and shoot surface area had a curvilinear relationship under field conditions, with shoot weight increasing much more quickly than shoot surface area due to shoot thickness and succulence increases [47]. That result was partially consistent with our observations in 'Da Hong' pitaya, where plantlet weight and plantlet surface area had a strong linear relationship $\left(r^{2}=0.8665\right)$. However, this conclusion was incongruent with the hypothesis of Mauseth [48], who suggested that succulent shoot volume should generally not affect 
surface area due to the shoot rib connection. Notably, the regression equations describing the relationships between (regeneration) shoot length and (regeneration) shoot surface area, and between plantlet weight and plantlet surface area as well as plantlet shoot volume, established in this study, will be helpful for further calculations of gas exchange rate [49] and leaf area index to estimate the best in vitro growth environment for pitaya.

\subsection{Cultivated Duration and Acclimatization}

Our preliminary results showed that the disinfected seeds of 'Da Hong' emerged after 1 week under aseptic conditions [35], a period that is consistent with previous reports for H. purpusii [21] but 3 weeks shorter than that for H. undatus [18]. The seedling segments regenerated shoots after 1 week of in vitro cultivation. Therefore, the total duration of 'Da Hong' micropropagation, including seed germination, shoot regeneration, shoot elongation to $4 \mathrm{~cm}$, and root induction, was 8 weeks. That was considerably shorter than the duration of micropropagation in $H$. undatus, in which the shoots took 60 days to develop from 1.5 to $2.0 \mathrm{~cm}[18,26]$. All plantlets grew well without disease symptoms at 4 weeks after transplantation, consistent with observations in other Hylocereus species [21,27,39]. These findings suggest that the disease risk of field-transplanted plantlets is rare.

\subsection{The Potential to Reduce Disease Risk in Plantlets and Renew Infected Orchards}

Pathogens typically have latent infectious characteristics on the host surface or in host organs. The infection pathway depends on the pathogens: both microbial (i.e., bacterial and fungal) and viral pathogens infect succulent shoots after mechanical injury [7,12], whereas microbial hyphae may penetrate plant cell walls and infect hosts when environmental conditions are suitable for mycelium development [11,13]. Host development status (e.g., young shoot, flower, or fruit) may also affect infection susceptibility. For example, $N$. dimidiatum infects young shoots and fruits $[8,50]$, while the symptoms of Colletotrichum spp. are manifested in mature shoots and fruits [10,11,51].

Viral and microbial infections can reduce fruit production by up to $40 \%$ [9]. Thus, various methodologies that minimize pathogen-associated losses have been proposed [9,13]. Micropropagation performed in aseptic agar media has been a helpful method for minimizing disease risks [14], because microbial infections can typically be identified in seedling explants using the agar plate method [15].

In the present study, robust micro-propagules were produced from disinfected seeds. It is difficult for microbes to invade seeds, and virus transmission through Hylocereus seeds and seed-derived seedlings has not been confirmed [12,52]. Therefore, using disinfected seeds for in vitro propagation of $H$. polyrhizus 'Da Hong' reduces disease risk in the resulting micro-propagules [7,53]. Blotter or ELISA methods will be needed for further detection of the predominant microorganisms of Hylocereus, including Cactus virus $X, N$. dimidiatum, and Colletotrichum spp., to confirm disinfection during and after micropropagation [15,54]. Although self-pollinating 'Da Hong' seedlings were used in the present study, there is the possibility of heterogeneity [55]; therefore, identification of genetic differentiation should be investigated in the future.

\section{Conclusions}

We reported a simple procedure for the in vitro micropropagation of robust 'Da Hong' pitaya. Adding AC to the MS culture medium accelerated plantlet growth and development. Although the shoot regeneration number was not drastically increased, the regenerated shoots were strong, robust, and capable of sustaining multiple subcultures. We also observed spontaneous rooting in 'Da Hong' segments during shoot development, which reduced the duration of the rooting process and shortened the overall culture period. We proved that MS medium supplemented with $200 \mathrm{mg} / \mathrm{L} \mathrm{AC}$ and $0.10 \mathrm{mg} / \mathrm{L}$ NAA was the best for shoot regeneration. In contrast, the best protocol for shoot development involved culture medium supplemented with $200 \mathrm{mg} / \mathrm{L}$ AC in combination with $0.20 \mathrm{mg} / \mathrm{L}$ NAA and $1.00 \mathrm{mg} / \mathrm{L}$ BAP. Successfully micropropagated 'Da Hong' pitaya could be used in 
orchards, providing new information in this context, valuable to produce robust seedlings of the genus Hylocereus tissue culture.

Supplementary Materials: The following supporting information can be downloaded at: https: / / www.mdpi.com/article/10.3390/horticulturae8020104/s1, Figure S1: In vitro shoot regeneration and root induction of Hylocereus polyrhizus 'Da Hong' from Murashige and Skoog (MS) medium supplemented with $0.05-0.20 \mathrm{mg} / \mathrm{L} \alpha$-naphthaleneacetic acid (NAA); Figure S2: Plantlet weight, including shoots and roots, and root/shoot ratio of Hylocereus polyrhizus 'Da Hong' grown on Murashige and Skoog (MS) medium supplemented with $\alpha$-naphthaleneacetic acid (NAA) alone.

Author Contributions: Conceptualization, J.-C.C. and Y.-C.L.; methodology, Y.-C.L.; software, Y.-C.L.; validation, J.-C.C.; formal analysis, Y.-C.L.; investigation, Y.-C.L.; resources, Y.-C.L.; data curation, Y.-C.L.; writing—original draft preparation, Y.-C.L.; writing-review and editing, J.-C.C.; supervision, J.-C.C.; project administration, J.-C.C.; funding acquisition, J.-C.C. All authors have read and agreed to the published version of the manuscript.

Funding: This study was supported by a grant from the Ministry of Science and Technology, Executive Yuan, Taiwan, Republic of China. Project code: MOST-109-2313-B-005-021-MY3 (to J.-C.C.).

Data Availability Statement: Data sets analyzed during the current study are available from the current author on reasonable request.

Acknowledgments: We would like to thank Y.H. Hsu for her valuable suggestions and technical assistance in this work. We are also grateful to M.C. Ho for her support with orchard management.

Conflicts of Interest: The authors declare no conflict of interest.

\section{References}

1. Zee, F.; Yen, C.-R.; Nishina, M. Pitaya (dragon fruit, strawberry pear). Fruits Nuts 2004, 9, 1-3.

2. Chien, Y.-C.; Chang, J.-C. Net houses effects on microclimate, production, and plant protection of white-fleshed pitaya. HortScience 2019, 54, 692-700. [CrossRef]

3. Chu, Y.-C.; Chang, J.-C. High temperature suppresses fruit/seed set and weight, and cladode regreening in red-fleshed 'Da Hong' pitaya (Hylocereus polyrhizus) under controlled conditions. HortScience 2020, 55, 1259-1264. [CrossRef]

4. Chu, Y.-C.; Chang, J.-C. Regulation of floral bud development and emergence by ambient temperature under a long-day photoperiod in white-fleshed pitaya (Hylocereus undatus). Sci. Hortic. 2020, 271, 109479. [CrossRef]

5. Jiang, Y.-L.; Yang, W.-J. Development of integrated crop management systems for pitaya in Taiwan. In Improving Pitaya Production and Marketing; Jiang, Y.-L., Liu, P.-C., Huang, P.H., Eds.; Food Fertilizer Technology Center Press: Taipei, Taiwan, 2015; pp. 73-78

6. Chiu, Y.C.; Lin, C.P.; Hsu, M.C.; Liu, C.P.; Chen, D.Y.; Liu, P.C. Cultivation and Management of Pitaya; Taiwan Agricultural Research Institute: Tainan, Taiwan, 2015; p. 93.

7. Liao, J.Y.; Chang, C.A.; Yan, C.R.; Chen, Y.C.; Deng, T.C. Detection and incidence of Cactus Virus X on pitaya in Taiwan. Plant Pathol. Bull. 2003, 12, 225-234.

8. Chuang, M.F.; Ni, H.F.; Yang, H.R.; Shu, S.L.; Lai, S.Y.; Jiang, Y.L. First report of stem canker disease of pitaya (Hylocereus undatus and H. polyrhizus) caused by Neoscytalidium dimidiatum in Taiwan. Plant Dis. 2012, 96, 906. [CrossRef]

9. Valencia-Botín, A.J.; Kokubu, H.; Ruiz, D.R. A brief overview on pitahaya (Hylocereus spp.) diseases. J. Prof. Assoc. Cactus 2013, 15, 42-48. [CrossRef]

10. Lin, C.-P.; Ann, P.-J.; Huang, H.-C.; Chang, J.-T.; Tsai, J.-N. Anthracnose of pitaya (Hylocereus spp.) caused by Colletotrichum spp., a new postharvest disease in Taiwan. J. Taiwan Agric. Res. 2017, 66, 171-183. [CrossRef]

11. Zakaria, L. Diversity of colletotrichum species associated with anthracnose disease in tropical fruit crops-A review. Agriculture 2021, 11, 297. [CrossRef]

12. Evallo, E.; Taguiam, J.D.; Balendres, M.A. A brief review of plant diseases caused by Cactus virus X. Crop Protect. 2021, $143,105566$. [CrossRef]

13. Zimmermann, H.G.; Granata, G. Insect pests and diseases. In Cacti: Biology and Uses; Nobel, P.S., Ed.; University of California Press: Berkeley, CA, USA, 2002; pp. 235-254.

14. Lema-Rumińska, J.; Kulus, D. Micropropagation of cacti-A review. Haseltonia 2014, 19, 46-63. [CrossRef]

15. Chohan, S.; Perveen, R.; Abid, M.; Naqvi, A.H.; Naz, S. Management of seed borne fungal diseases of tomato: A review. Pak. J. Phytopathol. 2017, 29, 193-200. [CrossRef]

16. Cassells, A.C. Pathogen and biological contamination management in plant tissue culture: Phytopathogens, vitro pathogens, and vitro pests. In Plant Cell Culture Protocols, 3rd ed.; Loyola-Vargas, V.M., Ochoa-Alejo, N., Eds.; Humana Press: Totowa, NJ, USA, 2012; pp. 57-80. [CrossRef]

17. Murashige, T.; Skoog, F. A revised medium for rapid growth and bio assays with tobacco tissue cultures. Physiol. Plant. 1962, 15, 473-497. [CrossRef] 
18. Dahanayake, N.; Ranawake, A.L. Regeneration of dragon fruit (Hylecereus undatus) plantlets from leaf and stem explants. Trop. Agric. Res. Ext. 2011, 14, 85-89. [CrossRef]

19. Sheng, W.K.W.; Sundarasekar, J.; Sathasivam, K.; Subramaniam, S. Effects of plant growth regulators on seed germination and callus induction of Hylocereus costaricensis. Pak. J. Bot. 2016, 48, 977-982.

20. Pérez-Molphe-Balch, E.; del Socorro Santos-Díaz, M.; Ramírez-Malagón, R.; Ochoa-Alejo, N. Tissue culture of ornamental cacti. Sci. Agric. 2015, 72, 540-561. [CrossRef]

21. De Feria, M.; Rojas, D.; Reyna, M.; Quiala, E.; Solìs, J.; Zurita, F. In vitro propagation of Hylocereus purpusii Britton \& Rose, a mexican species in danger of extinction. Biotecnol. Veg. 2012, 12, 77-83.

22. Hua, Q.; Chen, P.; Liu, W.; Ma, Y.; Liang, R.; Wang, L.; Wang, Z.; Hu, G.; Qin, Y. A protocol for rapid in vitro propagation of genetically diverse pitaya. Plant Cell Tissue Organ. Cult. 2014, 120, 741-745. [CrossRef]

23. Mohamed-Yasseen, Y. Micropropagation of pitaya (Hylocereus undatus Britton et Rose). Vitr. Cell. Dev. Biol. Plant 2002, 38, 427-429. [CrossRef]

24. Suman, K.; Rani, A.R.; Reddy, P.V. Response of dragon fruit (Hylocereus undatus) explants on MS media with growth regulators under in vitro for mass multiplication. Agric. Update 2017, 12, 2371-2375.

25. Trivellini, A.; Lucchesini, M.; Ferrante, A.; Massa, D.; Orlando, M.; Incrocci, L.; Mensuali-Sodi, A. Pitaya, an attractive alternative crop for mediterranean region. Agronomy 2020, 10, 1065. [CrossRef]

26. Yu, H.-L.; Zhang, W.; Zhu, Y.-Y. Studies on rapid propagation technology of stem segments in vitro of Hongxianmi Hylocereus undatus. J. Anhui Agric. Sci. 2009, 37, 3951-3952. [CrossRef]

27. Kari, R.; Lukman, A.L.; Zainuddin, R.; Ja'afar, H. Basal media for in vitro germination of red-purple dragon fruit Hylocereus polyrhizus. J. Agrobiotechnol. 2010, 1, 87-93.

28. Qin, J.; Wang, Y.; He, G.; Chen, L.; He, H.; Cheng, X.; Xu, K.; Zhang, D. High-efficiency micropropagation of dormant buds in spine base of red pitaya (Hylocereus polyrhizus) for industrial breeding. Int. J. Agric. Biol. 2017, 19, 193-198. [CrossRef]

29. Bidabadi, S.S.; Jain, S.M. Cellular, molecular, and physiological aspects of in vitro plant regeneration. Plants 2020, 9, 702. [CrossRef]

30. Wang, P.J.; Huang, L.C. Beneficial effects of activated charcoal on plant tissue and organ cultures. In Vitro 1976, 12, $260-262$. [CrossRef]

31. Santos-Díaz, M.S.; Pérez-Molphe, E.; Ramírez-Malagón, R.; Núñez-Palenius, H.G.; Ochoa-Alejo, N. Mexican threatened cacti: Current status and strategies for their conservation. In Species Diversity and Extinction; Tepper, G.H., Ed.; Nova Science Publishers, Inc. Press: New York, NY, USA, 2010; pp. 1-60.

32. Thomas, T.D. The role of activated charcoal in plant tissue culture. Biotechnol. Adv. 2008, 26, 618-631. [CrossRef]

33. Pérez Molphe Balch, E.; Reyes, M.E.P.; Amador, E.V.; Rangel, E.M.; del Rocío Morones Ruiz, L.; Lizalde-Viramontes, H.J Micropropagation of 21 species of mexican cacti by axillary proliferation. Vitr. Cell. Dev. Biol. Plant 1998, 34, 131-135. [CrossRef]

34. Peng, L.-C.; Qu, S.-P.; Su, Y.; Zhang, Y.-P.; Wang, L.-H. Study on rapid propagation of Hylocereus undatus by two steps. Southwest China J. Agric. Sci. 2014, 27, 2529-2533.

35. Lee, Y.-C.; Chang, J.-C. Effect of MS strengths and fruit storage duration at $4{ }^{\circ} \mathrm{C}$ on 'Da Hong' pitaya seed germination. HortScience, 2022; manuscript in preparation.

36. Abramoff, M.D.; Magalhães, P.J.; Ram, S.J. Image processing with ImageJ. Biophotonics Int. 2004, 11, 36-42.

37. Mauseth, J.D.; Halperin, W. Hormonal control of organogenesis in Opuntia polyacantha (Cactaceae). Am. J. Bot. 1975, 62, 869-877. [CrossRef]

38. Rubluo, A.; Marín-Hernández, T.; Duval, K.; Vargas, A.; Márquez-Guzmán, J. Auxin induced morphogenetic responses in long-term in vitro subcultured Mammillaria san-angelensis Sánchez-Mejorada (Cactaceae). Sci. Hortic. 2002, 95, 341-349. [CrossRef]

39. Viñas, M.; Fernández-Brenes, M.; Azofeifa, A.; Jiménez, V.M. In vitro propagation of purple pitahaya (Hylocereus costaricensis [F.A.C. Weber] Britton \& Rose) cv. Cebra. Vitr. Cell. Dev. Biol. Plant 2012, 48, 469-477.

40. Clayton, P.W.; Hubstenberger, J.F.; Phillips, G.C.; Butler-Nance, S.A. Micropropagation of members of the Cactaceae subtribe Cactinae. J. Am. Soc. Hortic. Sci. 1990, 115, 337-343. [CrossRef]

41. Angulo-Bejarano, P.I.; Paredes-López, O. Development of a regeneration protocol through indirect organogenesis in prickly pear cactus (Opuntia ficus-indica (L.) Mill). Sci. Hortic. 2011, 128, 283-288. [CrossRef]

42. Kim, Y.-S.; Hahn, E.-J.; Yeung, E.C.; Paek, K.-Y. Lateral root development and saponin accumulation as affected by IBA or NAA in adventitious root cultures of Panax ginseng C.A. Meyer. Vitr. Cell. Dev. Biol. Plant 2003, 39, 245-249. [CrossRef]

43. Elmongy, M.S.; Cao, Y.; Zhou, H.; Xia, Y. Root development enhanced by using indole-3-butyric acid and naphthalene acetic acid and associated biochemical changes of in vitro azalea microshoots. J. Plant Growth Regul. 2018, 37, 813-825. [CrossRef]

44. Mendes, A.F.S.; Cidade, L.C.; Otoni, W.C.; Soares-Filho, W.S.; Costa, M.G.C. Role of auxins, polyamines and ethylene in root formation and growth in sweet orange. Biol. Plant. 2011, 55, 375-378. [CrossRef]

45. Pan, M.J.; van Staden, J. The use of charcoal in in vitro culture-A review. Plant Growth Regul. 1998, 26, 155-163. [CrossRef]

46. Pan, M.J.; van Staden, J. Effect of activated charcoal, autoclaving and culture media on sucrose hydrolysis. Plant Growth Regul. 1999, 29, 135-141. [CrossRef]

47. De Cortázar, V.G.; Nobel, P.S. Biomass and fruit production for the prickly pear cactus, Opuntia ficus-indica. J. Am. Soc. Hortic. Sci. 1992, 117, 558-562. [CrossRef] 
48. Mauseth, J.D. Theoretical aspects of surface-to-volume ratios and water-storage capacities of succulent shoots. Am. J. Bot. 2000, 87, 1107-1115. [CrossRef] [PubMed]

49. Malda, G.; Backhaus, R.A.; Martin, C. Alterations in growth and crassulacean acid metabolism (CAM) activity of in vitro cultured cactus. Plant Cell Tissue Organ. Cult. 1999, 58, 1-9. [CrossRef]

50. Yi, R.H.; Lin, Q.L.; Mo, J.J.; Wu, F.F.; Chen, J. Fruit internal brown rot caused by Neoscytalidium dimidiatum on pitahaya in Guangdong province, China. Australas. Plant Dis. Notes 2015, 10, 13. [CrossRef]

51. Masyahit, M.; Sijam, K.; Awang, Y.; Satar, M.G.M. The first report of the occurrence of anthracnose disease caused by Colletotrichum gloeosporioides (Penz.) Penz. \& Sacc. on dragon fruit (Hylocereus spp.) in peninsular Malaysia. Am. J. Appl. Sci. 2009, 6, 902-912.

52. Maule, A.J.; Wang, D. Seed transmission of plant viruses: A lesson in biological complexity. Trends Microbiol. 1996, 4, 153-158. [CrossRef]

53. Ni, H.-F.; Huang, C.-W.; Hsu, S.-L.; Lai, S.-Y.; Yang, H.-R. Pathogen characterization and fungicide screening of stem canker of pitaya. J. Taiwan Agric. Res. 2013, 62, 225-234.

54. Gebeyaw, M. Review on: Impact of seed-borne pathogens on seed quality. Am. J. Plant Biol. 2020, 5, 77-81. [CrossRef]

55. Cisneros, A.; Tel-Zur, N. Genomic analysis in three Hylocereus species and their progeny: Evidence for introgressive hybridization and gene flow. Euphytica 2013, 194, 109-124. [CrossRef] 